Heinz Heimsoeth . Transzendentale Dialektik 



\section{Heinz Heimsoeth}

\section{Transzendentale Dialektik}

Ein Kommentar zu Kants Kritik der reinen Vernunft

Vierter Teil:

Die Methodenlehre

Mit einem Nachwort und Register für alle vier Teile

Walter de Gruyter - Berlin · New York 
(C)

1971 by Walter de Gruyter \& Co., vormals G. J. Göschen'sche Verlagshandlung - J. Guttentag, Verlagsbuchhandlung - Georg Reimer - Karl J. Trübner - Veit \& Comp., Berlin 30, Genthinet Str. 13 (Printed in Germany)

Alle Rechte, insbesondere das der Übersetzung in fremde Sprachen, vorbehalten. Ohne ausdrückliche Genehmigung des Verlages ist es auch nicht gestattet, dieses Buch oder Teile daraus auf photomechanischem Wege (Photokopie, Mikrokopie, Xerokopie) zu vervielfältigen.

Satz und Druck: Paul Funk, Berlin 30 